\title{
Prevalence of Giardia duodenalis among dogs seized by the Center for Control of Zoonoses (CCZ) of the city of Lages, Santa Catarina, Brazil
}

\author{
Rosiléia Marinho Quadros ${ }^{1}$, Paulo Henrique Exterckotter Weiss ${ }^{1}$, Geison Willian Ezequiel ${ }^{1}$, \\ Renato Batista Tamanho ${ }^{2}$, Geanice Lepo ${ }^{2}$, Marcio Rodrigues da Silva ${ }^{2}$, \\ Carlos Roberto João da Silva Junior ${ }^{2}$, Flávio Antonio Pacheco de Araujo ${ }^{3}$, \\ Luiz Claudio Miletti ${ }^{4^{*}}$
}

\footnotetext{
${ }^{1}$ Universidade do Planalto Catarinense, UNIPLAC, Lages, Brazil

${ }^{2}$ Centro de Controle de Zoonoses, Lages, Brazil

${ }^{3}$ Universidade Federal do Rio Grande do Sul, Porto Alegre, Brazil

${ }^{4}$ Universidade do Estado de Santa Catarina, Lages, Brazil; ${ }^{*}$ Corresponding Author: miletti@cav.udesc.br
}

Received 19 September 2012; revised 21 October 2012; accepted 28 October 2012

\begin{abstract}
The knowledge of the epidemiology of parasitic infections in stray and domestic animals, especially of its incidence and prevalence, is fundamental to adopting effective prophylactic measures. Stray dogs play an important role in environmental contamination favoring the transmission cycle of zoonotic agents. Among the parasitic infections that affect humans, Giardia duodenalis is the most common intestinal protozoa and was designated as a re-emerging infectious disease. This study aimed to determine the prevalence of $G$. duodenalis in dogs siezed by the Center for Control of Zoonoses (CCZ) of the city of Lages, Santa Catarina, Brazil using two diagnostic techniques. In 357 stool samples analysed, the prevalence of $G$. duodenalis cysts was $5.3 \%(19 / 357)$ and $4.8 \%(17 / 357)$ detected by floatation and sedimentation techniques, respectively. No correspondence between gender and age was found among the methods used for analyzing the infected dogs in this study. Our data suggested that two diagnostic techniques should be used in a complementary way to ensure that false negatives are not neglected.
\end{abstract}

Keywords: Giardia duodenalis; Dogs; Zoonoses; Brazil

\section{INTRODUCTION}

Urban growth and social change caused by human migration to the cities have favored the growth of the stray and domestic dog population in many developing coun- tries [1]. From an epidemiological standpoint, stray dogs play an important role in environmental contamination, since they do not receive anti parasitic treatments and circulate in public areas favoring the spread of parasites [2].

Among the parasitic infections that affect humans and represent public health problems, Giardia duodenalis is one of the most common intestinal protozoa, having a broad geographical distribution throughout the world $[3,4]$.

G. duodenalis (sin. G. intestinalis or G. lamblia) is a flagellated protozoan, whose life cycle consists of two stages: trophozoite and cyst, which contaminates food and water [5]. Cysts are usually responsible for transmitting the disease to the hosts, as they are resistant to changes in the environment, desiccation and gastric acidity from the stomach [6]. The infection is spread by the fecal-oral route to susceptible individuals and is influenced by the levels of environmental contamination and survival of the parasite [7]. The trophozoite inhabits the large intestine, but is not capable of invading the intestinal mucosa [8]. It affects the intestine, but less often affects the stomach [9], ileum and colon [10], and also the gallbladder [11].

The variety of vertebrate hosts is wide, including dogs, cats, rats, sheep, cattle, goats and horses, and also wild animals [12-14] The disease is responsible for malabsorption and diarrhea especially in children and immunosuppressed individuals $[15,16]$.

Although the flagellate is common in dogs and cats, it is rarely associated with clinical disease in these animals [17]. However, giardiasis have been reported in animals living in kennels and catteries, acting as potential sources of infection for new animals to be placed in the envi- 
ronment, which justifies the need to treat all animals regardless of whether they are experiencing symptoms or not $[18,19]$.

The coproparasitological technique is the most common laboratory procedure for the diagnosis of gastrointestinal parasitic infections. Different techniques can be used for the diagnosis of Giardia, according to the sensitivity and resources of the routine laboratory tests. Generally, the diagnosis depends on the identification of cysts in stools with or without diarrhea, trophozoites in stools from a patient with diarrhea, contents of duodenal aspiration or biopsies of intestinal mucosa [20]. The zinc sulfate centrifugal flotation technique [21] was the technique chosen for performing routine diagnosis of parasitic structures, especially Giardia cysts and/or trophozoites [14]. There are also indirect diagnostic methods, such as ELISA (Enzyme-Linked Immunoabsorbent Assay) and PCR, an important epidemiological tool since different Giardia genotype is associated with the clinical severity of the infection [22].

This study aimed to determine the prevalence of $G$. duodenalis in dogs seized by the Center for Control of Zoonoses (CCZ) of the city of Lages (Santa Catarina), using two different diagnostic techniques.

\section{MATERIAL AND METHODS}

The city of Lages is located in the state of Santa Catarina, southern Brazil. The geographic coordinates are: South latitude $270^{\circ} 48^{\prime}$ West longitude $500^{\circ} 20^{\prime}$ and about 916 meters altitude; its climate is subtropical with an average temperature of $14.3^{\circ} \mathrm{C}$. It has a population of 156,727 inhabitants; the growth rate of the population is 1.38 and its population density is of 59.27 inhabitants $/ \mathrm{km}^{2}$ [23]. The CCZ is a public institution maintained by the city of Lages. It belongs to the Municipal Health Secretariat and is responsible for preventing and controlling zoonoses in the city and developing sanitary and epidemiological surveillance systems.

According to the CCZ, the estimated dog population in Lages is of 25,000 animals, which represents an average of $0.16 \mathrm{dog} /$ inhabitant. For the research, dog feces were collected in the CCZ between June 2011 and July 2012. The study was approved by the Ethics Committee for Animal Experiments from the Center of Agroveterinary Sciences at the University of Santa Catarina (UDESC) under the protocol 134/2011.

\section{Samples and Parasitological Methods}

Fecal samples were collected directly from the rectum of 357 dogs seized by the CCZ and sent to the Parasitology Laboratory of the Universidade do Planalto Catarinense (UNIPLAC) and processed within 24 hours. The parasitological tests were performed using two methods for each sample, verifying the presence of cysts and/or trophozoites of $G$. duodenalis.

The methods chosen for the analysis were: 1) The centrifugal floatation technique: Two grams of feces were homogenized in $10 \mathrm{ml}$ of water and filter into a centrifuge tube and centrifuge at $400 \mathrm{~g}$ for $2 \mathrm{~min}$. The supernatant is removed and a solution of zinc sulfate $33 \%$ (density $=1.180$ ) is added and the tubes were shaken for 2 minutes. The tubes were centrifuged at 400 $\mathrm{g}$ for $2 \mathrm{~min}$. The upper solution was removed with a Pasteur pipette and put on a slide. Two drops of Lugol are added [21]. 2) Spontaneous sedimentation technique: Two grams of feces were homogenized in $10 \mathrm{ml}$ of water using a glass rod and filtered to a glass conical sedimenttation vessel. Water was added to the edge of the vessel. After approximately 1 hour, removed the sediment with Pasteur pipette and deposited on a slide. Two drops of Lugol were added [24,25]. The parasitic structures were visualized an optical microscope with the $40 \times$ objectives.

The chi-square test was used for statistical analysis, and the Test-t was used to compare the diagnosis methods and dog's gender, with a significance level of $\mathrm{p}<$ 0.05 .

\section{RESULTS}

The city is divided into 65 neighborhoods [26] and for the study, stool samples were collected from stray dogs seized in 62 neighborhoods (95.38\%). In 18 of those (29.03\%), all located in the periphery (Araucária, Caravágio, Ferrovia, Guarujá, Habitação, Maria Luiza, Penha, Petrópolis, Ponte Grande, Promorar, Santa Catarina, Santa Clara, Santo Antonio, Tributo, Várzea, Vila Maria, Vila Mariza and Vila Nova), the animals were infected with $G$. duodenalis cysts, as shown in Figure 1.

The 357 stray dogs consisted of 195 (54.6\%) females and 152 (45.4\%) males aged from 1 month to 10 years. Of the 357 stool samples analyzed, none of them showed signs of diarrhea. Cysts of $G$. duodenalis were found with a prevalence of 5.3\% (19/357) and 4.8\% (17/357) for floatation and sedimentation methods, respectively.

The zinc sulfate centrifugal flotation is the technique choose for performing routine diagnosis of parasitic structures and it has good diagnostic sensitivity [14], but the association of two evaluation techniques for G. duodenalis, in this case sedimentation technique, regardless their equivalence, should improved the diagnosis. The total positivity for cysts of $G$. duodenalis was 36 samples, of which 22 (61\%) were exclusively detected by one of the methods employed and 14 samples (39\%) were positive by two methods (Table 1). This means that if the two methods were not complimentary, $61 \%$ of the samples would be negative for the parasite. 


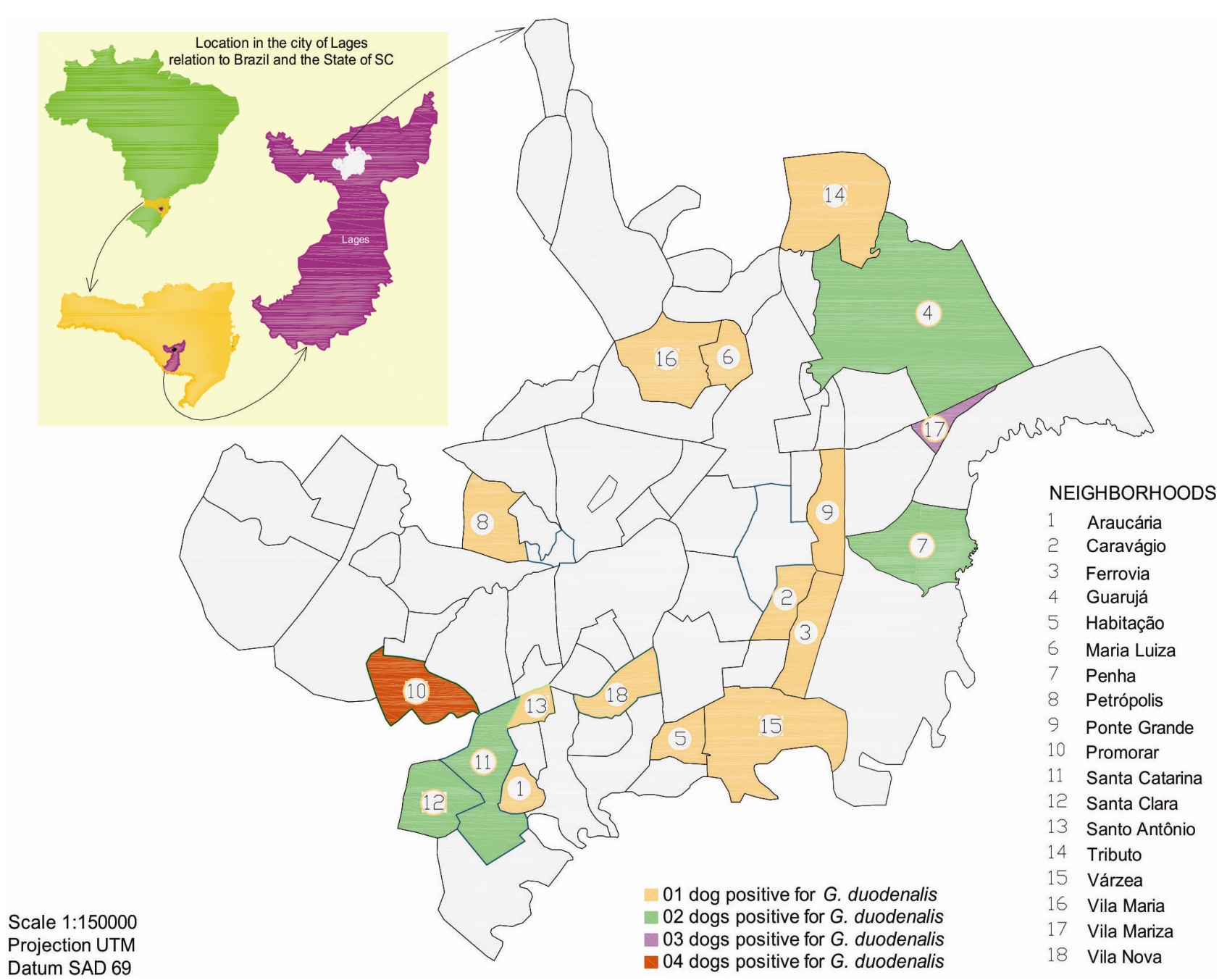

Figure 1. Distribution of the dogs seized by the CCZ in the neighborhoods of the city of Lages, in Santa Catarina.

Table 1. Compatibility of the results from the two diagnosis methods for G. duodenalis.

\begin{tabular}{cccc}
\hline Method & $\begin{array}{c}\text { Total } \\
\text { Detection }^{1}\end{array}$ & $\begin{array}{c}\text { Exclusive } \\
\text { Detection }\end{array}$ & $\begin{array}{c}\text { Common } \\
\text { Detection }\end{array}$ \\
\hline Flotation & 19 & 12 & 7 \\
Sedimentation & 17 & 10 & 7 \\
Total & 36 & 22 & 14 \\
\hline
\end{tabular}

${ }^{1}$ There is no dependency between gender and the methods used for the diagnosis of $G$. duodenalis $\left(\chi^{2}=0.7846^{\mathrm{ns}}\right)$.

Regarding age, it was verified through the t-test that the age of the females infected with $G$. duodenalis was similar to the age of the males. The age of the infected females detected by the flotation method was the same as the one detected by the sedimentation method, i.e., there is no difference between gender nor methods for the variable age (Table 2 ).

Through the chi-square test, it was found that there is no dependancy between the methods and dogs's gender,
Table 2. Infected dogs with G. duodenalis, according to sex and diagnosis methods.

\begin{tabular}{cccc}
\hline Method & Females & Males & Prob $<\mathrm{t}^{1}$ \\
\hline Flotation & $3.0 \pm 1.4$ & $4.3 \pm 3.5$ & 0.18 \\
Sedimentation & $2.0 \pm 1.1$ & $4.6 \pm 3.4$ & 0.19 \\
Prob $<\mathrm{t}^{2}$ & 0.46 & 0.42 & \\
\hline
\end{tabular}

${ }^{1}$ Comparison at line and ${ }^{2}$ column, using test t.

i.e., the presence of $G$. duodenalis maintains the same pattern between the two assessment methods, so the methods are equivalent in terms of frequency for the diagnosis of the protozoan.

Considering age, the prevalence of $G$. duodenalis occurred mainly in dogs aged up to six years (Table 3), and regardless of the method used for the diagnosis, about $80 \%$ of the animals were within the first three age groups. There was one case of positive sample, for which the age of the dog was not estimated by the vets of the CCZ. 
Table 3. Absolute and relative frequency (\%) of G. duodenalis according to the age of male and female dogs.

\begin{tabular}{|c|c|c|c|c|c|c|c|c|}
\hline \multirow{2}{*}{$\begin{array}{c}\text { Age } \\
\text { Groups }\end{array}$} & \multicolumn{4}{|c|}{ Flotation } & \multicolumn{4}{|c|}{ Sedimentation } \\
\hline & \multicolumn{2}{|c|}{ Female (\%) } & \multicolumn{2}{|c|}{ Male (\%) } & \multicolumn{2}{|c|}{ Female (\%) } & \multicolumn{2}{|c|}{ Male (\%) } \\
\hline$\leq 2$ & 2 & (33.3) & 5 & (38.5) & 3 & $(60.0)$ & 4 & $(30.0)$ \\
\hline 2.1 a 4 & 3 & $(50.0)$ & 2 & (15.4) & 1 & $(20.0)$ & 3 & (30.0) \\
\hline 4.1 a 6 & 1 & $(16.7)$ & 3 & (23.1) & 0 & $(0.0)$ & 2 & (20.0) \\
\hline 6.1 a 8 & 0 & $(0.0)$ & 2 & (15.4) & 0 & $(0.0)$ & 2 & $(0.0)$ \\
\hline 8.1 a 10 & 0 & $(0.0)$ & 0 & $(0.0)$ & 0 & $(0.0)$ & 0 & $(0.0)$ \\
\hline 10.1 a 12 & 0 & $(0.0)$ & 1 & (7.7) & 0 & $(0.0)$ & 0 & $(0.0)$ \\
\hline NI & 0 & $(0.0)$ & 0 & $(0.0)$ & 1 & (20.0) & 1 & (10.0) \\
\hline Total & 6 & & 13 & & 5 & & 12 & \\
\hline
\end{tabular}

\section{DISCUSSION}

There are many studies on prevalence of $G$. duodenalis in stray dogs populations worldwilde and particulary in Brazil [27]. Prevalence is variable and depends on a number of factors including age, living conditions, region studied and health status of the animal [28] and in diagnostic methodology employed as shown in this study.

In present work neighborhoods Vila Mariza and Promorar were the ones with the highest number of infected dogs with G. duodenalis (Figure 1) However, there is no explanation for these findings, since peripheral neighborhoods have the same physiographic and socio-economic characteristics. The neighborhood of Tributo was responsible for $10.08 \%$ (36/357) of the dogs seized during the study, mainly because of the close location to CCZ.

In this work it was found that positive results for Giardia cysts in dogs stool samples were different from other studies in Brazil. A prevalence of $80 \%$ in Rio de Janeiro (RJ), 70\% in Curitiba (PR), 34\% in Florianópolis (SC) and 32\% in Belo Horizonte (MG) was found by [29]. A prevalence of $41 \%$ in Uberlândia (MG) was found by [30], a close result to $44.3 \%$ in dogs from the municipality of Santa Maria (RS) [31], but this high prevalence in the study was attributed to the large number of young dogs (89.1\%). Also in the state of Rio Grande do Sul, in the city of Porto Alegre, Giardia cysts was found in 198 (38\%) of the 526 samples analyzed using centrifugal floatation technique method [32], and in Canoas (RS), using the same technique, $34.04 \%$ of dog's stool samples positive for the protozoan [33]. However, the data for the dogs in Lages were closer to data obtained in Guarulhos (SP) of 13.25\% (22/166) using different techniques from the ones used in this study [34].

The data obtained for these 357 samples were in agreement with other the authors $[35,36]$ that reported that the prevalence of Giardia, especially in dogs, shows variable rates, depending on geographical location, the method used for the diagnosis and the characteristics of the population studied. In practice, the negative results in stool samples for Giardia are common, due to either in- adequate sensitivity of the diagnostic tests or by intermittent removal of the parasite [37].

Comparative studies between dogs and children in their households in the city of Lages in 2005, found that $20 \%(20 / 100)$ of the children and 18\% (19/105) of the dogs were Giardia-positive, according centrifugal floatation technique $[38,39]$. These more significant data than those found recently for the same region can be explained by the low temperatures and high levels of rainfall registered in the city in the year of 2011, which may have contributed to low environmental resistance of the parasite and by the improvement of living conditions experienced by the population, especially due to the implementation of sewage systems in various districts of the city that started in 2010.

Although no significant differences was found between males and females infected with the protozoa, as was observed in the studies in Porto Alegre [32] and in northern Greece [40], a higher number of infected adult males than females was observed [41]. According to the authors, neutered dogs tend to show a reduced prevalence of infection compared with sexually active animals. But, according to [42], the large number of infections occurred in females (7\%) compared to males (3.4\%).

No dependency relationship was found between age and the methods applied for the diagnosis using the Chi-square test. As reported by [43] no significant difference for cysts of Giardia among puppies in kennels (39\%) and puppies in houses (34\%) [43]. But, [44] and [45] mentioned that apparently healthy dogs have a prevalence of $10 \%$ to $20 \%$ for Giardia compared to animals aged less than 12 months, and this frequency ranged between 36\% - 50\% in his work in northern Greece [40], found positive results of $14,8 \%$ for dogs infected with the protozoan aged up to six months and 3,3\% for dogs aged between 6 months and 10 years.

In Germany, Giardia infections occur more often in puppies housed in kennels due to the crowded conditions compared to adult and companion dogs [46]. This higher susceptibility of animals aged less than 12 months to the protozoan can be attributed to a certain degree of resistance that is acquired with age. Stray animals may be 
more exposed to contaminated water, food and feces, increasing the risk of infection for the group, although it has not been proven in this study.

No dependency relationship was found in this study between the methods of flotation and sedimentation in relation to gender and age of the dogs infected with $\mathrm{G}$. duodenalis seized by the CCZ. But, although the zinc sulfate centrifugal flotation technique (Faust et al. technique) is the technique chosen for the diagnosis of Giardia cysts and/or trophozoites, the two assessment methods should be used as complimentary methods.

Although the frequency of $G$. duodenalis have shown different distributions in the various geographic regions, its increase or decrease is strongly correlated with socioeconomic, environmental, ecological and prevention facptors that require a global commitment from not only the different health professionals, but also from politicians to allocate resources in order to conduct interactive control programs.

\section{REFERENCES}

[1] Batista, C.S.A., Azevedo, S.A., Alves, C.J., Morais, Z., Clementino, I.J., Lima, F.S. and Neto, J.O. (2004) Soroprevalência de leptospirose em cães errantes da cidade de Patos, Estado da Paraíba, Brasil. Brazilian Journal of Veterinary Research and Animal Science, 41, 131-136. doi:10.1590/S1413-95962004000200009

[2] Scaini, C.J., Toledo, R.N., Lovatel, R., Dionello, M.A., Gatti, F.A., Susin, L. and Signoruni, V.R.M. (2003) Environment contamination by helminth eggs and larvae in dog feces from central area of Cassino Beach, Rio Grande do Sul. Revista da Sociedade Brasileira de Medicina Tropical, 36, 617-619.

[3] Tashima, N.T., Simões, M.J.S., Leite, C.Q.F., Fluminhan, A., Nogueira, M.A. and Malaspina, C.A. (2009) Classic and molecular study of Giardia duodenalis in children from a daycare Center in the region of Presidente Prudente, São Paulo, Brazil. Revista do Instituto de Medicina Tropical, 51, 19-24. doi:10.1590/S0036-46652009000100004

[4] Klan, S.M., Debnath, C., Pramanik, A.K., Xiao, L., Nozaki, T. and Ganguly, S. (2011) Molecular evidence for zoonotic transmission of Giardia duodenalis among dairy farm workers in West Bengal, India. Veterinary Parasitology, 178, 342-345. doi:10.1016/j.vetpar.2011.01.029

[5] Díaz, V., Campos, M., Lozano, J., Mañas, I. and González, J. (1996) Aspects of animal giardioses in Granada province (Southern Spain). Veterinary Parasitology, 64, 171176. doi:10.1016/0304-4017(95)00923-X

[6] Adam, R.D. (1991) The biology of Giardia spp. Microbiological Reviews, 55, 706-732.

[7] Gomes, A.D., Barreta, C., Ziegler, D.P., Sausen, L., Stoever, N., Sangioni, L.A., Vogel, F.S.F., Monteiro, S.G. and Zanella, A. (2008) Prevalência de Cryptosporidium spp e Giardia sp em equinos estabulados no Jockey Club de Santa Maria-RS, Brasil. Ciência Rural, 38, 2662-

\section{5. doi:10.1590/S0103-84782008005000012}

[8] Babaei, Z.H., Ormazdi, O., Akhlaghi, L., Rezaie, S., Razmjou, E., Soltani-Arabshahi, S.K., Meamar, A.R. and Hadighi, R. (2008) Molecular characterization of the Iranian isolates of Giardia lamblia: Application of the glutamate dehydrogenase gene. Iranian Journal of Public Health, 37, 75-82.

[9] Doglioni, C., De Boni, M., Cielo, R., Laurino, L., Pelasio, P., Braidotti, P. and Viale, G. (1992) Gastric giardiasis. Journal of Clinical Pathology, 45, 964-967. doi:10.1136/jcp.45.11.964

[10] Howard, L.H., Fink, D.S., Lubin, J. and Robinson, M.J. (1995) Giardiasis diagnosed by biopsy of the colon and terminal ileum: Unusual sites for a common pathogen. American Journal of Gastroenterology, 90, 1011-1013.

[11] Goldstein, F., Thornton, J.J. and Szydlowski, T. (1978) Billiary tract dysfunction in Giardiasis. American Journal of Digestive Diseases, 23, 559-560. doi:10.1007/BF01072702

[12] Thompson, R.C.A., Smith, A., Limbery, A.J., Averis, S., Morris, K.D. and Wayne, A.F. (2010) Giardia in western Australian wildlife. Veterinary Parasitology, 170, $207-$ 211. doi:10.1016/j.vetpar.2010.02.012

[13] Meireles, P., Montiani-Ferreira, F. and Thomaz-Soccol, V. (2008) Survey of giardiosis in household and shelter dogs from metropolitan areas of Curitiba, Paraná state, southern Brazil. Veterinary Parasitology, 152, 241-248. doi:10.1016/j.vetpar.2007.12.025

[14] Souza-Dantas, L.M., Bastos, O.P.M., Brener, B., Salomão, M., Guerrero, J. and Labarthe, N.V. (2007) Técnica de centrífugo-flutuação com sulfato de zinco no diagnóstico de helmintos. Ciência Rural, 37, 904-906. doi:10.1590/S0103-84782007000300051

[15] Hunter, P.R. and Thompson, R.C.A. (2005) The zoonotic transmission of Giardia and Cryptosporidium. International Journal for Parasitology, 35, 1181-1190. doi:10.1016/j.ijpara.2005.07.009

[16] Read, C.M., Monis, P.T. and Thompson, R.C.A. (2004) Discrimination of all genotypes of Giardia duodenalis at the glutamate dehydrogenase locus using PCR-RFLP. Infection, Genetics and Evolution, 4, 125-130. doi:10.1016/j.meegid.2004.02.001

[17] Palmer, C.S., Traub, R.J., Robertson, I.D., Devlin, G., Rees, R. and Thompson, R.C.A. (2010) Determining the zoonotic significance of Giardia and Cryptosporidium in Australian dogs and cats. Veterinary Parasitology, 154, 142-147. doi:10.1016/j.vetpar.2008.02.031

[18] Elígio-García, L., Cortés-Campos, A. and Jiménez-Cardoso, E. (2008) Classification of Giardia intestinalis isolates by multiple polymerase chain reaction (multiplex). Parasitology Research, 103, 797-800. doi:10.1007/s00436-008-1042-0

[19] Robertson, I.D., Irwin, J.P., Limbery, A.J. and Thompson, R.C.A. (2000) The role of companion animals in the emergence of parasitic zoonoses. International Journal for Parasitology, 30, 1369-1377. doi:10.1016/S0020-7519(00)00134-X

[20] Huber, F., Bomfim, T.C. and Gomes, R.S. (2003) Compa- 
ração da eficiência da técnica de sedimentação pelo formaldeído-éter e da técnica de centrífugo-flutuação modificada na detecção de oocistos de Giardia sp. e oocistos de Cryptosporidium sp. em amostras fecais de bezerros. Revista Brasileira de Parasitologia Veterinária, 12, 135-137.

[21] Faust, E.C., D’antonio, J.S., Odom, V., Miller, M.J., Peres, C., Sawitz, W., Thomen, L.F., Toble, J. and Walker, J.H. (1938) A critical study of clinical laboratory techniques for the diagnosis of protozoan cyst and helminth egg in feces. American Journal of Tropical Medicine, 18, 169183.

[22] Yong, T.S., Park, S.J., Hwang, U.W., Lee, K.W., Min, D. and Rim, H.J. (2000) Genotyping of Giardia lamblia isolates from humans in China and Korea using ribosomal DNA Sequences. Journal of Parasitology, 86, 887-891.

[23] Instituto Brasileiro de Geografia e Estatística (IBGE) (2010) Fundação Sistema Estadual de Análise de Dados. Censo Demográfico, Santa Catarina. http://www.ibge.gov.br/cidadesat/topwindow.htm?1

[24] Lutz, A. (1991) O Schistosoma mansoni e a schistosomose segundo observações feitas no Brasil. Memórias do Instituto Oswaldo Cruz, 11, 121-155.

[25] Hoffmann, W.A., Pons, J.A. and Janer, J.L. (1934) The Sedimentation Concentration Method in Schistosomiasis mansoni. Journal of Tropical Medicine and Public Health, 9, 283-298.

[26] Prefeitura Municipal ee Lages (PML) (2012) Disponível. http://www.lages.sc.gov.br/perfil.php.

[27] Klimpel, S., Heukelbach, J., Pothmann, D. and Ruckert, S. (2010) Gastrointestinal and ectoparasites from urban stray dogs in Fortaleza (Brazil): High infection risk for humans? Parasitology Research, 107, 713-719. doi:10.1007/s00436-010-1926-7

[28] Tangtrongsup, S. and Scorza, V. (2010) Update on the diagnosis and management of Giardia spp. Infections in dogs and cats. Topics in Companion Animal Medicine, 25, 155-162. doi:10.1053/j.tcam.2010.07.003

[29] Gennari, S.M. and Souza, S. (2002) Giardiasis. Fort Dodge Saúde Animal LTDA, Boletim Técnico, São Paulo, $13 \mathrm{p}$.

[30] Mundim, M.J., Souza, S.S.Z., Hortêncio, S.M. and Cury, M.C. (2003) Frequência de Giardia spp. por duas técnicas de diagnóstico em fezes de cães. Arquivo Brasileiro de Medicina Veterinária e Zootecnia, 55, 770-773. doi:10.1590/S0102-09352003000600016

[31] Silva, A.S., Maurer, C.G., Gasperi, D., Pessoa, G.A., Zanette, R.A., Antonow, R.R., Vogel, F.S.F., Sangioni, L.A. and Monteiro, S.G. (2008) Protozoários em cães de canis de Santa Maria-RS. Revista da FZVA, 15, 191199.

[32] Bartmann, A. and Araújo, F.A.P. (2004) Frequência de Giardia lamblia em cães atendidos em clinicas veterinárias de Porto Alegre, RS, Brasil. Ciência Rural, 34, 1093-1096. doi:10.1590/S0103-84782004000400020

[33] Beck, C., Araújo, F.A.P., Olicheski, A.T. and Breyer, A.S.
(2005) Freqüencia da infecção por Giardia lamblia (Kunstler, 1882) em cães (Canis familiaris) avaliada pelo Método de Faust e cols. (1939) e pela Coloração da Auramina, no município de Canoas, RS, Brasil. Ciência Rural, 35, 126-130. doi:10.1590/S0103-84782005000100020

[34] Santos, S.V. and Castro, J.M. (2006) Ocorrência de agentes parasitários com potencial zoonótico de transmissão em fezes de cães domiciliados no Município de Guarulhos, SP. Arquivos do Instituto Biológico, 73, 255257.

[35] Nikolic, A., Kulisic, Z. and Bojkovski, J. Giardiasis as a zoonosis: The prevalence of Giardia in dogs in Belgrade. Acta Veterinaria, 43, 239-243.

[36] Marcel, A.M., Manso, E.O., Pêrez, H.S., Hernández, O.G. and Melendéz, J.A.S. (1994) Frecuencia de Giardiasis en algunas especies de animales domésticos de la provincia de Villa Clara, Cuba. Veterinaria México, 25, 337-340.

[37] Irwin, P.J. (2002) Companion animal parasitology: A clinical perspective. International Journal for Parasitology, 32, 581-593. doi:10.1016/S0020-7519(01)00361-7

[38] Arruda, A., Quadros, R.M., Marques, S.M.T. and Rocha, G.C. (2008) Prevalência de giardiasis em crianças e seus cães da periferia urbana de Lages, Santa Catarina. Revista da FZVA, 15, 126-134.

[39] Almeida, C.G., Marques, S.M.T., Miquelluti, D.J. and Quadros, R.M. (2010) Giardiasis em crianças e cães do mesmo domicílio e de bairros periféricos de Lages, Santa Catarina. Revista Ciência \& Saúde, 3, 9-13.

[40] Papazahariadou, M., Founta, A., Papadopoulos, E., Chliounakis, S., Antoniadou-Sotiriadou, K. and Theodorides, Y. (2007) Gastrointestinal parasites of shepherd and hunting dogs in the Serres Prefecture, Northern Greece. Veterinary Parasitology, 148, 170-173. doi:10.1016/j.vetpar.2007.05.013

[41] Oliveira-Siqueira,T.C.G. and Amarante, A.F.T. (2001) Prevalence of intestinal parasites in dogs from São Paulo State, Brazil. Veterinary Parasitology, 103, 19-27. doi:10.1016/S0304-4017(01)00575-1

[42] Horejs, R. and Koudela, B. (1994) Giardiasis in dogs in a breeding kennel. Veterinary medicine, 39, 93-101.

[43] Hahn, N.E., Glaser, C.A., Hird, D.W. and Hirsh, D.C. (1998) Prevalence of Giardia in the feces of pups. Journal of the American Veterinary Medical Association, 19, 21428-21429.

[44] Barr, S.C. and Bowman, D.D. (1994) Giardiasis in dogs and cats. The compendium Continuing Education for the Practicing Veterinarian, 16, 603-609.

[45] Lallo, M.A. (1994) Ocorrência de Giardia sp em cães na Grande São Paulo. Congresso Brasileiro da Anclivepa, 16, Anais, Goiânia, 37.

[46] Barutzki, D., Schimmel, A., Schaper, R. (2000) Eficácia de palmoato de pirantel, febantel e praziquantel contra Giardia em cães naturalmente contaminados. Informativo Técnico, Giardia, 5-7. 